\title{
Fatty Acid Composition of Oil from Groundnuts and Oyster Nuts Grown in Uganda
}

\author{
Juliet Hatoho Musalima ${ }^{1}$, Patrick Ogwok ${ }^{1} \&$ Diriisa Mugampoza ${ }^{1}$ \\ ${ }^{1}$ Department of Food Technology, Faculty of Science, Kyambogo University, Kampala, Uganda \\ Correspondence: Juliet Hatoho Musalima, Department of Food Technology, Faculty of Science, Kyambogo \\ University, Kampala, Uganda. Tel: 256-701-617-002. E-mail: julietmusalima@ gmail.com
}

Received: August 29, 2019

Accepted: September 27, 2019 Online Published: October 11, 2019

doi:10.5539/jfr.v8n6p37

URL: https://doi.org/10.5539/jfr.v8n6p37

\begin{abstract}
This study determined the fatty acid (FA) composition of oil from groundnuts and oyster nuts in Uganda. The FA composition was determined by Gas Chromatography/Mass Spectrometry with FID. Oil from groundnuts contained 39.71 to $55.89 \%$ oleic, 20.21 to $35.59 \%$ linoleic and 11.91 to $17.16 \%$ palmitic acids. Oil from Serenut cultivars contained cis 11-eicosenoic acid (C20.1), cis 11, 14 eicosadienoic acid (C20.2) and cis 11, 14, 17 eicosatrienoic acid $(\mathrm{C} 20.3 \omega 3)$ which were not detected in traditional cultivars. Oyster nut oil was high in linoleic acid at 41.02 to $44.86 \%$ and palmitic acid at 33.58 to $38.11 \%$ while oleic acid was low with amounts $<10 \%$. The polyunsaturated to saturated FA ratios of oil from groundnuts and oyster nuts were $>0.45$, the minimum recommended by FAO. The atherogenic (AI) and thrombogenic indices (TI) of $<1$ and the hypocholesterolemic to hypercholesterolemic index $(\mathrm{h} / \mathrm{H})$ of $>4$ in groundnut oil were favorable for cardiovascular health. Indices for oyster nut oil were $\leq 1$ for AI and $>1$ for TI. The $\mathrm{h} / \mathrm{H}$ was low compared to that of groundnut oil. Results showed little distinction between the FA compositions of oil from traditional and improved groundnuts suggesting that breeding may not have significant effect on major FAs. Oyster nut oil contained saturated and unsaturated FA in a ratio of 1:1. The lipid health indices for groundnut oil were within recommendations while those of oyster nuts were less desirable. Oyster nut oil should therefore be consumed with moderation.
\end{abstract}

Keywords: fatty acids, groundnut, oil, oyster nut, Uganda

\section{Introduction}

Nuts have been recognised as a high fat food group (Hollis \& Mattes, 2007). Most nuts contain low levels of saturated and high amounts of unsaturated fatty acids (Kris-Etherton et al., 1999). Fatty acids (FA) in nuts have structural and metabolic roles in the body (Arbex et al., 2015). Groundnuts (Arachis hypogea L.) are the second most widely grown and consumed legumes in Uganda after common beans (Phaseolus vulgaris). Their production is in Northern, Eastern and Southern parts of Uganda with Eastern region being the highest producer (Okello, Biruma, \& Deom, 2010). In North and Eastern Uganda, groundnuts are valued as cash crops and a valuable source of oil and protein (Mugisha, Lwasa, \& Mausch, 2014; Okello et al., 2010). Groundnuts contain approximately 40 to $50 \%$ oil (Ntare, Diallo, Ndjeunga \& Waliyar, 2008). Despite being an excellent source of oil, the highest proportion of groundnuts produced in Uganda is consumed as snacks, stew and paste with low value added to the crop ( Okello et al., 2010; Mugisha, Lwasa, \& Mausch, 2014). Vegetable oils are important sources of polyunsaturated fatty acids (PUFA), alpha linolenic and linoleic acids (Yehuda, 2003). Utilization of the oil depends on FA composition and fat soluble vitamins (Shad, Pervez, Zafar, Nawaz, \& Khan, 2012; Strayer, Belcher, Fine, \& Mcbrayer, 2006). Groundnut oil is considered healthier than saturated oil due to its high monounsaturated FA content and is resistant to rancidity because of the anti oxidant vitamins (Asibuo et al., 2008; Shad et al., 2012).

The groundnut research program at the National Arid and Semi-Arid Resources Research Institute (NaSARRI) in Serere, Uganda is focused on developing groundnut varieties with improved agronomic characteristics. Breeding at NaSSARI resulted in large scale production and commercialization of improved groundnut (Serenut) cultivars. These cultivars are high yielding, high quality, resistant to diseases, and quick maturing (Okello et al., 2010; Okello, Deom, Puppala, Monyo, \& Bravo-Ureta, 2016).

Today's consumers are concerned about the nutritional value and safety of foods they consume. It is therefore 
important to establish any nutritional and safety differences between new varieties and traditional ones. Even though modification was intended for another purpose, it may result in some unintended positive or negative changes in the product. Little information however, is available on the nutritional profile of these cultivars in comparison with their traditional counterparts.

Oyster nut, Telfairia pedata, is a perennial climbing vine and a member of the Cucurbitaceae family (Jumbe et al., 2016). It is common in Tanzania, Kenya and some parts of Uganda. Oyster nuts contain 55 to $60 \%$ oil (Ajayi et al., 2004; Hopkins \& Chisholm, 1964). Oyster nuts are eaten raw or cooked are especially mentioned as source of food for women during the lactating period. The nuts have been reported to have other non-food uses ascribed to the properties of their oil. Ajayi et al. (2004) asserted that oyster nuts may stay in good condition for up to eight years despite their high concentration of oil. Oyster nut oil however, may have limited application due to lack of information regarding its chemical composition.

Despite the indiscriminate utilisation of groundnuts and their products, there is scant information on the FA composition of oil from the Serenut and traditional cultivars as well as oyster nuts in Uganda. To establish whether breeding improves the nutritional properties of the oil, this study determined the FA composition of oil from Serenut and traditional groundnut cultivars. Oyster nut oil was characterised to establish its constituent fatty acids. Determining these parameters could add to the nutritional data base for crops grown in Uganda and allow for consumption from an informed perspective.

\section{Materials and Methods}

\subsection{Sample Collection and Preparation}

Fourteen improved cultivars (Serenuts 1 to 14) and six traditional groundnut cultivars (Acholi white, Igola, Egoromoit, Rudu white, Rudu red and Red beauty) were studied. Serenut 1 to 14 were collected from National Arid and Semi-Arid Research Resources Institute (NaSARRI) in Serere. Traditional cultivars were purchased from markets in Soroti, Arapai, and Achorimongin markets in Teso sub-region, Eastern Uganda. Groundnuts were shelled, sorted, hulled and finely crushed to obtain groundnut flour. Oyster nuts were obtained from Kamuli district in Eastern, Dokolo district in Northern, and Luwero district in central Uganda and transported to the laboratory. Nuts were cleaned and sorted according to gender, the flat nuts were classified as female and the creased nuts as male. A total of 18 samples comprising of 9 male and 9 female were peeled to remove the fibrous shell. Splitting of the inner shell was done using a knife to release the oil-bearing cotyledon. Oyster nut cotyledons were pounded using a mortar and pestle to obtain a paste. Groundnut flours and oyster nut paste were stored in the refrigerator $\left(4^{\circ} \mathrm{C}\right)$ prior to oil extraction. All assays were done in triplicate.

\subsection{Oil Extraction}

Oil extraction was done according to Bligh and Dyer (1959). Groundnut flour and oyster nut paste were separately weighed $(10 \mathrm{~g})$ into a $250 \mathrm{ml}$ flat bottomed flask then chloroform was added $(100 \mathrm{ml})$. Flask contents were mixed using an ultraturax homogenizer (IKA T18, Bergkirchen, Germany) for $2 \mathrm{~min}$. The mixture was transferred into a $40 \mathrm{ml}$ dionex vial and centrifuged at $2000 \mathrm{rpm}$ for $5 \mathrm{~min}$. The chloroform layer was filtered through a filter paper (Macherey-nagel, $125 \mathrm{~mm}$ ) containing anhydrous sodium sulphate. Twenty milliliters of the filtrate was concentrated under a stream of nitrogen at $40{ }^{\circ} \mathrm{C}$.

\subsection{Fatty Acid Composition}

\subsubsection{Preparation of Fatty Acid Methyl Esters}

Fatty acid methyl esters (FAME) were prepared according to AOAC (2000) method number 969.33. Fat was weighed $(0.5 \mathrm{~g})$ in a $40 \mathrm{ml}$ glass vial and diethyl ether added $(2 \mathrm{ml})$. The mixture was then vortexed until oil was dissolved. Methanolic potassium hydroxide was added $(0.5 \mathrm{ml})$ and the mixture allowed to react for 15 min. during which the solution became cloudy due to soap formation.

\subsubsection{Extraction of the Fatty Acids from the Soap Solution}

Distilled water was added $(2 \mathrm{ml})$ to the FAME solution followed by $10 \mathrm{ml}$ of hexane. The mixture was vortexed to allow phase separation. The organic layer was transferred to a clean test tube then distilled water was added (2 $\mathrm{ml})$. The mixture was allowed to stand to allow phase separation. This was repeated until the water used to wash the organic layer showed no color change with phenolphthalein. The organic layer was transferred (1 ml) to a 1.5 $\mathrm{ml} \mathrm{GC}$ vial and injected $(1 \mu \mathrm{l})$ onto a $30 \mathrm{~m} \times 0.32 \mathrm{~mm}$ x $0.5 \mu \mathrm{m}$ solgel wax column with polyethylene-glycol as the stationary phase and helium gas at $20 \mathrm{psi}$ as the mobile phase. The column was mounted in a GC/FID (Varian chrompack CP-3800, USA). The injector temperature was $260^{\circ} \mathrm{C}$. The temperature of the column was kept at $50^{\circ} \mathrm{C}$ for $5 \mathrm{~min}$. after injection and thereafter increased to $180{ }^{\circ} \mathrm{C}$ at a rate of $20^{\circ} \mathrm{C} / \mathrm{min}$., followed by an increase of 
$2^{\circ} \mathrm{C} / \mathrm{min}$ to $200^{\circ} \mathrm{C}$, held for $11 \mathrm{~min}$. and then finally ramped to $250^{\circ} \mathrm{C}$ at $2^{\circ} \mathrm{C} / \mathrm{min}$. and held for $2.5 \mathrm{~min}$. Fatty acids were identified by analyzing a reference standard mixture (Supelco 47885-U, Sigma Aldrich, Belgium) under the same conditions as the test portion. The retention distances of the standard were compared with those of the test portion. The esters appeared in order of increasing number of carbon atoms and of increasing level of unsaturation for the same number of carbon atoms. Calculation of the peaks was by normalization which assumes all components of test portion represented on the chromatograms so that the sum of the peaks represents $100 \%$ of the constituents.

\subsection{Iodine Value}

Iodine value was calculated from the fatty acid composition using the method of Hashim et al.(1993).

$$
\begin{aligned}
& \text { IV }=(\% \text { Oleic acid X 0.8601) }+(\% \text { Linoleic acid X 1.7321 })+(\text { Eicosanopentanoic acid X 0.7854) } \\
& 2.5 \text { Lipid Health Indices }
\end{aligned}
$$

\subsubsection{Atherogenic Index and Thrombogenic Indices}

Atherogenic index (AI) and thrombogenic index (TI) were calculated according to the following equations by Ulbricht and Southgate (1991).

$$
\begin{gathered}
\text { Atherogenic index }=(\mathrm{C} 14.0 \mathrm{x} 4+\mathrm{C} 16.0+\mathrm{C} 18.0) /\left(\sum \text { MUFA }+\sum \omega 6 \mathrm{PUFA}+\sum \omega 3 \mathrm{PUFA}\right) \\
\text { Thrombogenic index }=(\mathrm{C} 14.0+\mathrm{C} 16.0+\mathrm{C} 18.0) /(0.5 \mathrm{xMUFA}+0.5 \mathrm{x} \omega 6 \mathrm{PUFA}+3 \mathrm{x} \omega 3 \mathrm{PUFA})+\frac{\omega 3}{\omega 6}
\end{gathered}
$$

\subsubsection{Hypocholesterolemic/Hypercholesterolemic Index}

This index indicates potential of a lipid to balance between the good and bad cholesterol. It was calculated from the equation by Santos-Silva, Bessa, and Santos-Silva (2002).

$$
\frac{h}{H}=(C 18.1 \omega 9+C 18.2 \omega 6+C 20.4 \omega 6+C 18.3 \omega 3+C 20.5 \omega 3+C 22.6 \omega 3) /(C 14+C 16)
$$

h: Hypocholesterolemic

$\mathrm{H}$ : Hypercholesterolemic

\subsection{Statistical Analysis}

Samples were analysed in triplicate and data presented as mean \pm standard deviation (SD). One-way analysis of variance (ANOVA) with a Turkey's least significant difference (LSD) test was used in SPSS version 17.0 (SPSS, Chicago, IL, USA) to evaluate the differences in fatty acids. Differences were considered statistically significant at $\mathrm{p}<0.05$.

\section{Results and Discussion}

The percent FA composition of oil from groundnuts and oyster nuts are presented in Tables 1 and 2, respectively. Oils were found to contain variable levels of FA as discussed below.

\subsection{Groundnut Oil}

The dominant fatty acids (FA) in groundnut oil were oleic (C18.1), linoleic (C18.2) and palmitic (C16.0) acids with amounts more than $10 \%$ (Table 1). Approximately $80 \%$ of FA in oil from all cultivars were unsaturated (Table 3). Oleic (C18.1) as the major unsaturated FA varied from 39.71 to $55.89 \%$. This finding is close to the data reported by Khetarpaul, Jood, \& Goyal (2007) and Dorni, Paras, Gunendra, \& Longvah (2018) who reported $48.90 \%$ and $53.77 \%$ oleic acid (C18.1), respectively. Linoleic acid (C18.2) ranged from 20.21 to $35.59 \%$. Levels of linoleic acid (C18.2) were in agreement with the findings of Achola et al. (2017) who reported 26.79 to $33.44 \%$ while Dorni, Paras, Gunendra, \& Longvah (2018) reported $26.96 \%$ linoleic acid (C18.2) in groundnut oil. Similarly, Gulluoglu, Bakal, Onat, Sabagh, \& Arioglu (2016) reported 2 to $43 \%$ linoleic acid (C18.2) in groundnut oil. Palmitic acid (C16.0) concentration varied from 11.91 to $17.16 \%$. Findings were consistent with data by Achola et al. (2017) who reported a range of 14.61 to $18.6 \%$ palmitic acid (C16.0) in Serenuts 5 to 10. Shahidi (2005) and Özcan (2010) presented slightly lower ranges of 8 to14\% and 7.63 to $11.41 \%$ palmitic acid (C16.0), respectively, in groundnut oil. Stearic acid (C18.0) ranged from not detected (nd) to $4.93 \%$. Berry (1982) reported 3.17 to 3.68\% stearic acid (C18.0) while Achola et al. (2017) obtained 2.19 to $3.46 \%$ stearic acid (C18.0) in Serenuts 5 to 10. Levels of oleic (C18.1), linoleic, (C16.0) and stearic acid $(\mathrm{C} 18.0)$ varied significantly $(\mathrm{p}<0.05)$ indicating composition differences among the cultivars. Similarly, behenic acid (C22.0) levels were higher in the traditional cultivars compared to the Serenuts. Oil from red beauty (RB) had the highest amount of behenic acid. Other FAs such as gamma linolenic (C18.3 $\omega 6)$, alpha 
linolenic (C18.3 13$)$, arachidic (C20.0), eicosenoic (C20.1) and eicosadienoic (C20.2) occurred in amounts less than $2 \%$ in all cultivars. Levels of these FA were more pronounced in oils from traditional than Serenut cultivars. Arachidic acid (C20.0) is a characteristic FA in groundnuts and their products. The level of arachidic acid (C20.0) should not exceed $4.8 \%$ in groundnut oil (Codex, 2001). Dorni, Paras, Gunendra, \& Longvah (2018) and Özcan (2010) reported 1.44 to $2.36 \%$ and $1.42 \%$ arachidic acid (C20.0), respectively, in groundnut oil. The levels of arachidic acid in this study agreed with reports of the aforementioned scholars. Cis 11-eicosenoic acid (C20.1), cis 11, 14 eicosadienoic acid (C20.2) and cis 11, 14, 17 eicosatrienoic acid (C20.303) were detected in oil from Serenut cultivars and not in the other cultivars. The presence of these FA in oil from the Serenut cultivars may be attributed to breeding or growth environment.

Table 1. Fatty acid composition (\%) of oil from groundnuts

\begin{tabular}{|c|c|c|c|c|c|c|c|c|c|c|c|}
\hline GNC & $\mathrm{C} 16.0$ & $\mathrm{C} 18.0$ & $\mathrm{C} 18.1$ & $\mathrm{C} 18.2$ & $\mathrm{C} 18.3 \omega 3$ & $\mathrm{C} 18.3 \omega 6$ & $\mathrm{C} 20.0$ & $\mathrm{C} 20.1$ & $\mathrm{C} 20.2$ & $\mathrm{C} 20.3 \omega 3$ & $\mathrm{C} 22$ \\
\hline S1R & $15.73 \pm 0.11^{\mathrm{e}}$ & $2.13 \pm 0.10^{\mathrm{a}}$ & $50.28 \pm 0.61^{\text {fghi }}$ & $26.06 \pm 0.49^{\text {cd }}$ & $1.09 \pm 0.07^{\mathrm{i}}$ & $0.34 \pm 0.03^{\text {cde }}$ & $1.02 \pm 0.07^{\mathrm{ab}}$ & nd & $1.42 \pm 0.14^{\text {bcde }}$ & $0.52 \pm 0.36^{\mathrm{bc}}$ & $1.09 \pm 0.16^{\text {bcdefg }}$ \\
\hline $\mathrm{S} 2 \mathrm{~T}$ & $14.84 \pm 0.14^{\text {cde }}$ & nd & $52.28 \pm 0.88^{\mathrm{j}}$ & $25.96 \pm 0.79^{\mathrm{cd}}$ & $1.05 \pm 0.04^{\mathrm{i}}$ & $0.36 \pm 0.02^{\text {cde }}$ & nd & $1.24 \pm 0.02^{\mathrm{de}}$ & $1.05 \pm 0.06^{\mathrm{b}}$ & $1.40 \pm 0.08^{\mathrm{e}}$ & $1.48 \pm 0.00^{\mathrm{fg}}$ \\
\hline S3R & $14.51 \pm 0.27^{\text {cde }}$ & $2.89 \pm 0.21^{\text {cde }}$ & $54.85 \pm 0.14^{\mathrm{k}}$ & $21.68 \pm 0.21^{\mathrm{ab}}$ & $0.08 \pm 0.01^{\mathrm{bc}}$ & $0.28 \pm 0.00^{\text {abcde }}$ & nd & $1.10 \pm 0.03^{\mathrm{c}}$ & $1.41 \pm 0.28^{\text {bcde }}$ & $1.45 \pm 0.07^{\mathrm{e}}$ & $1.41 \pm 0.01^{\mathrm{efg}}$ \\
\hline S4T & $13.62 \pm 0.64^{\mathrm{bc}}$ & $4.15 \pm 0.10^{f}$ & $55.05 \pm 0.70^{\mathrm{k}}$ & $21.94 \pm 0.53^{\mathrm{b}}$ & $0.08 \pm 0.01^{\mathrm{bc}}$ & $0.34 \pm 0.02^{\text {cde }}$ & nd & $0.68 \pm 0.03^{\mathrm{b}}$ & $1.57 \pm 0.03^{\mathrm{de}}$ & $1.60 \pm 0.13^{\mathrm{e}}$ & $0.85 \pm 0.07^{\text {bcd }}$ \\
\hline S5R & $14.84 \pm 0.50^{\text {cde }}$ & $2.76 \pm 0.08^{\mathrm{cd}}$ & $48.71 \pm 0.65^{\mathrm{fg}}$ & $27.16 \pm 0.99^{\mathrm{de}}$ & $0.05 \pm 0.00^{\mathrm{ab}}$ & $0.57 \pm 0.05^{\mathrm{de}}$ & nd & $1.32 \pm 0.10^{\text {ef }}$ & $1.06 \pm 0.03^{\mathrm{bc}}$ & $1.66 \pm 0.12^{\mathrm{e}}$ & $1.59 \pm 0.17^{\mathrm{g}}$ \\
\hline S6T & $15.88 \pm 0.16^{\mathrm{ef}}$ & $3.40 \pm 0.18^{\mathrm{e}}$ & $50.29 \pm 0.13^{\text {ghi }}$ & $25.78 \pm 0.22^{\mathrm{cd}}$ & $0.07 \pm 0.01^{\mathrm{abc}}$ & $0.51 \pm 0.02^{\mathrm{de}}$ & nd & $0.70 \pm 0.01^{\mathrm{b}}$ & $1.08 \pm 0.01^{\mathrm{bc}}$ & $1.06 \pm 0.15^{\mathrm{d}}$ & $1.07 \pm 0.02^{\text {bcdef }}$ \\
\hline S7T & $14.61 \pm 1.26^{\text {cde }}$ & $3.15 \pm 0.27^{\mathrm{de}}$ & $46.31 \pm 0.54^{\text {cd }}$ & $30.79 \pm 0.86^{\mathrm{i}}$ & $0.06 \pm 0.02^{\mathrm{abc}}$ & $0.02 \pm 0.00^{\mathrm{ab}}$ & $0.12 \pm 0.00^{\mathrm{a}}$ & $1.20 \pm 0.01^{\mathrm{d}}$ & $1.48 \pm 0.02^{\text {cde }}$ & $0.65 \pm 0.05^{\mathrm{e}}$ & $1.46 \pm 0.03^{\operatorname{defg}}$ \\
\hline S8R & $13.78 \pm 0.18^{\text {bcd }}$ & $3.14 \pm 0.05^{\mathrm{de}}$ & $48.63 \pm 0.52^{\mathrm{ef}}$ & $29.25 \pm 0.22^{\text {gh }}$ & $0.23 \pm 0.01^{\mathrm{e}}$ & $0.24 \pm 0.03^{\mathrm{abcd}}$ & $0.06 \pm 0.00^{\mathrm{a}}$ & $1.15 \pm 0.07^{\mathrm{cd}}$ & $1.75 \pm 0.45^{\mathrm{e}}$ & $0.23 \pm 0.01^{\mathrm{ab}}$ & $1.33 \pm 0.04^{\text {cdefg }}$ \\
\hline S9T & $14.56 \pm 0.63^{\text {cde }}$ & $2.08 \pm 0.06^{\mathrm{a}}$ & $45.92 \pm 0.30^{\mathrm{bcd}}$ & $31.91 \pm 0.56^{\mathrm{ij}}$ & $0.27 \pm 0.01^{\mathrm{e}}$ & $0.28 \pm 0.01^{\mathrm{abcd}}$ & nd & $1.33 \pm 0.04^{\mathrm{ef}}$ & $1.41 \pm 0.21^{\text {bcde }}$ & $0.26 \pm 0.04^{\mathrm{ab}}$ & nd \\
\hline S10R & $15.09 \pm 0.05^{\mathrm{de}}$ & $2.44 \pm 0.22^{\mathrm{ab}}$ & $51.85 \pm 0.70^{\mathrm{ij}}$ & $24.67 \pm 0.45^{\mathrm{c}}$ & nd & $0.19 \pm 0.01^{\mathrm{abcd}}$ & nd & $1.36 \pm 0.03^{\mathrm{f}}$ & $1.26 \pm 0.18^{\mathrm{bcd}}$ & $1.63 \pm 0.10^{\mathrm{e}}$ & $1.36 \pm 0.02^{\mathrm{defg}}$ \\
\hline S11T & $13.79 \pm 0.07^{\mathrm{bcd}}$ & $2.36 \pm 0.20^{\mathrm{ab}}$ & $46.45 \pm 1.03^{\mathrm{cd}}$ & $34.02 \pm 0.39^{\mathrm{k}}$ & $0.97 \pm 0.01^{\mathrm{h}}$ & $0.31 \pm 0.15^{\mathrm{abc}}$ & $0.92 \pm 0.07^{\mathrm{ab}}$ & nd & nd & nd & $0.95 \pm 0.07^{\text {bcde }}$ \\
\hline S12R & $15.41 \pm 0.34^{\mathrm{e}}$ & $2.64 \pm 0.19^{\mathrm{abc}}$ & $52.11 \pm 0.09^{j}$ & $27.57 \pm 0.26^{\mathrm{ef}}$ & nd & $0.37 \pm 0.03^{\text {bcde }}$ & $1.02 \pm 0.04^{\mathrm{ab}}$ & nd & nd & nd & $0.98 \pm 0.15^{\text {bcdef }}$ \\
\hline S13T & $14.63 \pm 0.38^{\text {cde }}$ & $2.36 \pm 0.15^{\mathrm{ab}}$ & $50.30 \pm 0.49^{\mathrm{ghi}}$ & $30.61 \pm 0.12^{\mathrm{hi}}$ & nd & $0.97 \pm 0.07^{\text {cde }}$ & $0.69 \pm 0.02^{\mathrm{ab}}$ & nd & nd & nd & $0.76 \pm 0.58^{\mathrm{b}}$ \\
\hline S14R & $14.86 \pm 0.83^{\text {cde }}$ & $2.65 \pm 0.04^{\mathrm{abc}}$ & $49.73 \pm 0.39^{\mathrm{fgh}}$ & $28.93 \pm 0.63^{\mathrm{fg}}$ & nd & $0.97 \pm 0.07^{\mathrm{f}}$ & $1.03 \pm 0.06^{\mathrm{b}}$ & nd & nd & nd & $1.33 \pm 0.27^{\text {cdefg }}$ \\
\hline AW & $17.16 \pm 0.11^{\mathrm{f}}$ & $4.88 \pm 0.12^{\mathrm{h}}$ & $39.71 \pm 0.65^{\mathrm{a}}$ & $35.59 \pm 0.39^{1}$ & nd & $0.35 \pm 0.31^{\text {cde }}$ & $0.55 \pm 0.47^{\mathrm{ab}}$ & nd & nd & nd & $0.83 \pm 0.08^{\mathrm{bc}}$ \\
\hline IGO & $14.83 \pm 0.25^{\text {cde }}$ & $2.63 \pm 0.00^{\mathrm{abc}}$ & $50.86 \pm 0.45^{\text {hij }}$ & $28.87 \pm 0.22^{\mathrm{fg}}$ & nd & $0.13 \pm 0.01^{\mathrm{g}}$ & $2.70 \pm 0.21^{\mathrm{c}}$ & nd & nd & nd & $0.78 \pm 0.09^{\mathrm{b}}$ \\
\hline $\mathrm{RR}$ & $12.78 \pm 0.24^{\mathrm{ab}}$ & $4.21 \pm 0.48^{\mathrm{ff}}$ & $44.74 \pm 0.18^{\mathrm{bc}}$ & $30.86 \pm 0.66^{\mathrm{i}}$ & $0.14 \pm 0.01^{\mathrm{cd}}$ & nd & nd & nd & nd & nd & $3.27 \pm 0.12^{\mathrm{h}}$ \\
\hline RW & $12.68 \pm 0.17^{\mathrm{ab}}$ & $4.80 \pm 0.38^{\mathrm{gh}}$ & $44.28 \pm 0.08^{b}$ & $33.08 \pm 0.18^{\mathrm{jk}}$ & $0.21 \pm 0.02^{\mathrm{de}}$ & nd & nd & nd & nd & nd & $3.28 \pm 0.05^{\mathrm{h}}$ \\
\hline EGT & $13.75 \pm 0.34^{\mathrm{bcd}}$ & $4.93 \pm 0.23^{\mathrm{h}}$ & $55.89 \pm 0.12^{\mathrm{k}}$ & $20.21 \pm 0.18^{\mathrm{a}}$ & $0.67 \pm 0.02^{\mathrm{g}}$ & nd & nd & nd & nd & nd & $3.49 \pm 0.09^{\mathrm{hi}}$ \\
\hline $\mathrm{RB}$ & $11.91 \pm 0.14^{\mathrm{a}}$ & $4.74 \pm 0.20^{\mathrm{fgh}}$ & $46.90 \pm 0.49^{\mathrm{de}}$ & $30.76 \pm 0.11^{\mathrm{hi}}$ & $0.59 \pm 0.02^{\mathrm{f}}$ & nd & nd & nd & nd & nd & $3.86 \pm 0.15^{\mathrm{i}}$ \\
\hline
\end{tabular}

Data are expressed as percentages of total fatty acid methyl esters; Values are means of triplicate determinations, values followed by the same letter within each column are not significantly different ( $\mathrm{p}>0.05)$ nd: not detected; GNC: Groundnut cultivar; S: Serenut; R: red;T: Tan; AW: Acholi White; IGO: Igola; RR: Rudu Red; RW: Rudu White; EGT: Egoromoit; RB: Red Beauty.

\subsection{Oyster Nut Oil}

Oyster nut oil had high amounts of palmitic acid (C16.0) and linoleic acid (C18.2) but had low amount of oleic acid (C18.0). Palmitic acid (C16.0) ranged from 33.58 to 38.11\% (Table 2). This concurs with the concentrations obtained by Hopkins and Chisholm (1964) and Nyagah (2016) who reported 35\% and 32.03\% palmitic acid (C16.0) in oyster nut oil from South Africa and Kenya, respectively. Minzangi, Mpiana, Samvura, Kaaya, Bertrand, \& Kadima, 2015 examined nuts from DR Congo and obtained a lower level of Palmitic acid (C16.0) at 14.06\%. Palmitic acid (C16.0) has been positively associated with high serum cholesterol and hence cardiovascular risk (Galli and Calder, 2009; Fattore and Fanelli, 2013; Mancini et al., 2015 and Carta et al., 2017).

The high amount of palmitic acid (C16.0) in this study suggests that oyster nut oil may not favour cardiovascular health. In addition, high levels of palmitic acid (C16.0) may enhance metabolic complications such as insulin resistance and decreased oxidation of FA and glucose in muscles hence their accumulation in tissues (Iggman \& Risérus, 2017). However, moderate consumption of oils rich in palmitic acid (C16.0) could provide health benefits as it forms a significant part of cell membrane phospholipids (Calder, 2015). Stearic acid in oil ranged from 9.47 to $13.60 \%$. Hopkins and Chisholm (1964) reported 14\% and Nyagah (2016), 10.31\% stearic acid (C18.0). Contrary to our findings, Minzangi et al. (2015) obtained $9.3 \%$ stearic acid (C18.0). In the body, stearic acid is converted to oleic acid. This conversion may help to lower plasma cholesterol (Bonanome \& Grundy, 1988; Strayer et al., 2006; Mente et al., 2017). It is, therefore, implied that diet containing more stearic than palmitic acid may improve plasma lipid profile. Saturated FA that were detected in amounts less than $1.0 \%$ included; butyric acid (C4.0) caproic (C9.0), undecanoic (C11.0), lauric (C12.0), tridecanoic (C13.0), myristic (C14.0), heptadecanoic (C17.0), arachidic (C20.0), heneicosanoic (C20.1), tricosanoic (C23.0) and nervonic acid (C24.0). There were no significant differences ( $p>0.05)$ in the levels of different FA based on location or gender. Linoleic acid (C18.2) was the major unsaturated FA detected and it ranged from 41.02 to $44.86 \%$. This result is 
close to that obtained by Hopkins \& Chisholm (1964) at 44\% though slightly lower than that of Nyagah (2016) at $53.66 \%$. The levels of linoleic acid (C18.2) in this study doubled the $22.03 \%$ obtained by Minzangi et al. (2015). Linoleic acid ( C18.2) has been reported to lower total serum cholesterol, a positive attribute in reducing cardiovascular risk (Ristić-Medić, Vučić, Takić, \& Karadžić, Ivana and Glibetić, 2013). Oleic acid (C18.1) ranged from 5.69 to $8.10 \%$ (Table 2). While other scholars reported low levels of oleic acid (C18.1) at $<10 \%$, Minzangi et al. (2015) presented $41.77 \%$. Levels of Alpha linolenic acid (C18.3 103$)$ in oil were less than 2\%. Literature sources, (Hopkins \& Chisholm, 1964; Jumbe et al., 2016) indicate that alpha linolenic acid (C18.303) levels were either too low or undetected.

Table 2. Fatty acids (\%) in oyster nut oil

\begin{tabular}{|c|c|c|c|c|c|c|c|c|c|c|c|}
\hline Location & C16.0 & $\mathrm{C} 18.0$ & C18:1 & C18:2 & $18.3 \omega 3$ & $18.3 \omega 6$ & C20.1 & $\mathrm{C} 20.2$ & $\mathrm{C} 22.1 \omega 9$ & $\mathrm{C} 23.0$ & $\mathrm{C} 24.0$ \\
\hline \multicolumn{12}{|l|}{ Dokolo } \\
\hline Male & $38.11 \pm 0.96^{\mathrm{a}}$ & $13.60 \pm 0.21^{\mathrm{a}}$ & $5.93 \pm 0.26^{\mathrm{a}}$ & $41.02 \pm 1.02^{\mathrm{a}}$ & nd & nd & nd & nd & nd & $0.03 \pm 0.00^{\mathrm{a}}$ & nd \\
\hline Female & $36.39 \pm 3.99^{a}$ & $11.49 \pm 3.07^{\mathrm{a}}$ & $8.08 \pm 2.05^{\mathrm{a}}$ & $44.86 \pm 2.44^{\mathrm{a}}$ & $0.03 \pm 0.00^{\mathrm{a}}$ & $0.06 \pm 0.01^{\mathrm{a}}$ & nd & $0.02 \pm 0.00^{\mathrm{a}}$ & nd & $0.13 \pm 0.00^{\mathrm{a}}$ & nd \\
\hline \multicolumn{12}{|l|}{ Kamuli } \\
\hline Male & $38.72 \pm 3.37^{\mathrm{a}}$ & $10.47 \pm 0.56^{\mathrm{a}}$ & $5.69 \pm 2.09^{\mathrm{a}}$ & $42.88 \pm 3.77^{\mathrm{a}}$ & nd & nd & nd & nd & nd & $0.16 \pm 0.00^{\mathrm{a}}$ & nd \\
\hline Female & $37.21 \pm 3.19^{a}$ & $10.29 \pm 1.29^{\mathrm{a}}$ & $7.16 \pm 1.70^{\mathrm{a}}$ & $43.64 \pm 3.51^{\mathrm{a}}$ & nd & nd & nd & nd & nd & nd & $0.03 \pm 0.00^{\mathrm{a}}$ \\
\hline \multicolumn{12}{|l|}{ Luwero } \\
\hline Male & $35.32 \pm 5.01^{\mathrm{a}}$ & $9.47 \pm 2.88^{\mathrm{a}}$ & $8.10 \pm 4.15^{\mathrm{a}}$ & $44.62 \pm 1.22^{\mathrm{a}}$ & nd & $0.23 \pm 0.00^{\mathrm{a}}$ & $0.22 \pm 0.01 \mathrm{a}$ & $0.01 \pm 0.00^{\mathrm{a}}$ & $0.12 \pm 0.00^{\mathrm{a}}$ & nd & nd \\
\hline Female & $33.58 \pm 3.02^{\mathrm{a}}$ & $13.56 \pm 2.76^{\mathrm{a}}$ & $6.85 \pm 1.58^{\mathrm{a}}$ & $43.44 \pm 2.06^{\mathrm{a}}$ & $0.01 \pm 0.00^{\mathrm{a}}$ & $0.30 \pm 0.01^{\mathrm{a}}$ & $0.20 \pm 0.00 \mathrm{a}$ & $0.13 \pm 0.00^{\mathrm{a}}$ & $0.14 \pm 0.00^{\mathrm{a}}$ & nd & nd \\
\hline
\end{tabular}

Data are expressed as percentages of total fatty acid methyl esters, Values are means of triplicate determinations; values followed by the same letter within each column are not significantly different $(\mathrm{p}>0.05)$ nd: not detected.

\subsection{Lipid Health Indices for Groundnut Oil}

The polyunsaturated to saturated FA ratio (P/S) measures the tendency of the diet to influence the incidence of coronary heart disease (S`imaT, Bogdanovic', Poljak, \& Petric `evic', 2015). This ratio is also important in determining the cholesterolemic effect of dietary lipids. Foods with P/S ratio above 0.45 (FAO, 2010) are considered beneficial due to their potential to lower serum cholesterol (Kostik, Memeti, \& Bauer, 2013). The beneficial effect is even more significant when the P/S ratios are $>1$. The P/S of groundnut oil ranged from 0.99 to 2.15 (Table 3). Nile and Park (2013) and Johnson, Saikia, Mathur, \& Agarwal (2009) obtained P/S ratios of 1.8 and 2.28 for groundnut oil. The high $\mathrm{P} / \mathrm{S}$ ratios in this study suggests that consumption of diet rich in groundnut oil is beneficial for human health. Oils with high $\mathrm{P} / \mathrm{S}$ ratios have higher nutritional value than ones with less (Kostik et al., 2013). Ramprasath, Jones, Buckley, Woollett, \& Heubi (2012) reported that serum cholesterol concentrations are hiked with diets rich in SFA while the opposite effect is provided by diets containing high levels of PUFA. Consumption of diets with a high P/S ratio reduces plasma total and LDLcholesterol concentrations. Similarly Wen and Chao (1998), suggested that high ratio of P/S is crucial in keeping serum and liver cholesterol low. Experimental data by Iggman and Risérus (2017) suggests that partial replacement of SFA by PUFA hence increasing the P/S ratio may reduce cardiovascular risk. This is in agreement with report from expert consultation of FAO in 2010 on fats and FA in human nutrition (FAO, 2010).

The polyunsaturated to monounsaturated FA (P/M) ratio of oil ranged from 0.39 to 0.91 . Polyunsaturated and monounsaturated FAs are linked to reduction of atherosclerosis and cardiovascular disease ( Kris-Etherton, 1999; Harlioğlu and Yilmaz, 2011). Diets rich in monounsaturated FA are neutral while polyunsaturated FA lower plasma lipids (Wen and Chao, 1998; Bos et al., 2010). No clear recommendations are available for P/M ratio however, Wen \& Chao (1998), experimented with different P/M ratios and reported that high ratios lowered plasma and liver cholesterol and triglycerides. Findings of their experiments suggested that diets containing oil with a P/M ratio of 2.5 reduce the plasma and liver cholesterol of human subjects. Our results were far below the threshold given by the above scholars.

The monounsaturated to saturated FA ratio (M/S) of groundnut oil varied from 1.65 to 3.25 (Table 3). Nile and Park (2013) obtained M/S ratio of 1.06 for groundnut oil. The M/S ratio of this study is slightly higher. Diets with high M/S ratio of $>1$ decrease plasma HDL-C and triacylglycerides (Yang, Lin, Chang, \& Chien, 2017). Sinanoglou, Batrinou, Mantis, Bizelis, \& Miniadis-meimaroglou (2013) and Calder (2015) suggested that MUFA are heart protective while SFA may increase risk of cardiovascular disease. The high M/S ratio in this research suggests a healthy balance of FA in groundnuts.

The ratio of omega- 6 to omega-3 ( $\omega 6 / \omega 3)$ of groundnut oil varied from not detected (nd) to 228.55. where omega -3 FAs were detected, all the ratios exceeded the optimal range (4:1) suggested by Simopoulos (2010). This is attributed to the very low levels of omega 3 FA in the oil and higher levels of omega-6. Johnson et al. 
(2009) obtained $\omega 6 / \omega 3$ of 7.5 for groundnut oil while Nile and Park, (2013), reported $\omega 6 / \omega 3$ value of 25.0. Literature reports on this ratio are highly variable. Some scholars did not report any ALA in groundnut oil while others reported very low amounts hence the high ratios. Omega- 3 and omega- 6 produce eicosanoids with conflicting effects in the body, omega-3 being anti-inflammatory while omega- 6 eicosanoids support formation of thrombus, atheromas and obesity (Simopoulos, 2008, 2016; Alabdulkarim, Bakeet, \& Arzoo, 2012) . The oleic to linoleic $(\mathrm{O} / \mathrm{L})$ acid ratio of groundnut oil varied from 1.12 to 2.77. Shad et al. (2012) obtained an O/L ratio of 3.53 to 19.79 and suggested that high O/L ratio is stable to oxidation (Shad et al., 2012). Among studied oil, Egoromoit exhibited the highest $\mathrm{O} / \mathrm{L}$ ratio implying that its oil have better oxidative stability than the other oils.

Atherogenic and thrombogenic indices are used to assess nutritional quality of lipids (S imaT et al., 2015). The atherogenic Index (AI) of groundnut oil ranged from 0.18 to 0.29 while the thrombogenic index (TI) ranged from 0.31 to 0.58 (Table 3). These ranges were close to the range for some vegetable oils as reported by Turan (2007). Different recommendations have been suggested for AI and TI. According to Hernández-martínez, Gallardo-velázquez, Osorio-, Castañeda-pérez, \& Uribe-hernández (2016) levels of <1 are favourable while Ulbricht \& Southgate (1991) recommended an upper limit of 0.5 for both AI and TI.. The AI and TI of groundnut oil is comparable to the respective indices; 0.17 to 0.19 and 0.30 to 0.34 reported by Kou, Sabolová, Hor, \& Rys, (2018) for oats. Similarly, Attia, Al-harthi, Korish, \& Shiboob, $(2015 ; 2017)$ reported a TI range of 0.38 to 0.78 for eggs. The TI and AI indices of groundnut oil were within recommended levels for good cardiovascular health.

Hypocholesterolemic to hypercholesterolemic index $(\mathrm{h} / \mathrm{H})$ indicates potential of a lipid to balance between the good and bad cholesterol. Hernández-martínez et al. (2016) and Osmari, Cecato, Macedo, \& Souza (2011) suggested that high $\mathrm{h} / \mathrm{H}$ of $>1$ may be beneficial to human health. The Hypocholesterolemic to hypercholesterolemic index for groundnut oil ranged from 4.41 to 6.53 . The $\mathrm{h} / \mathrm{H}$ observed for groundnut oil was close to that (6.14) reported for olive oil (Hashempour-Baltork, Torbati, Azadmard-Damirchi, \& Savage, 2018). The high $\mathrm{h} / \mathrm{H}$ observed in this work implies that consumption of groundnut oil may result in reduced cardiovascular risk.

\subsection{Iodine Values for Groundnut Oil}

The iodine values (IV) groundnut oil were all in accordance to the recommended range of 86 to 106 except Egoromoit, with the lowest IV at 83.08 (Table 3). The highest IV in the Serenuts were observed for Serenut 11T and $13 \mathrm{~T}$ were 98.88 and 96.27, respectively. Among traditional cultivars, Acholi white and Rudu white had the highest IV of 95.79 and 95.38. the iodine values in this study were in agreement with the range reported by Asibuo, (2008) at 85.77 to 98.43 for groundnuts.

Table 3. Total fatty acids (\%) and lipid health indices of oil from groundnuts

\begin{tabular}{|c|c|c|c|c|c|c|c|c|c|c|c|c|c|}
\hline GNC & SFA & MUFA & PUFA & TUFA & IV & $\mathrm{O} / \mathrm{L}$ & $\omega 6 / \omega 3$ & $\mathrm{M} / \mathrm{S}$ & $\mathrm{P} / \mathrm{S}$ & $\mathrm{P} / \mathrm{M}$ & AI & TI & $\mathrm{h} / \mathrm{H}$ \\
\hline S1R & $20.10 \pm 0.16 d^{\text {efg }}$ & $50.39 \pm 0.58^{\mathrm{fg}}$ & $29.37 \pm 0.42^{\text {de }}$ & $79.76 \pm 0.16^{\text {cde }}$ & $88.28 \pm 0.84^{\text {cd }}$ & 1.93 & 16.97 & 2.51 & 1.46 & 0.58 & 0.23 & 0.41 & 4.87 \\
\hline S2T & $16.47 \pm 0.13^{\mathrm{b}}$ & $53.58 \pm 0.88^{\mathrm{i}}$ & $29.82 \pm 0.85^{\mathrm{de}}$ & $83.41 \pm 0.13^{\text {gh }}$ & $89.94 \pm 0.62^{\mathrm{de}}$ & 2.01 & 10.74 & 3.25 & 1.81 & 0.56 & 0.18 & 0.31 & 5.30 \\
\hline S3R & $18.94 \pm 0.07^{\mathrm{def}}$ & $56.05 \pm 0.14^{\mathrm{j}}$ & $24.93 \pm 0.19^{\mathrm{b}}$ & $80.99 \pm 0.06^{\mathrm{def}}$ & $84.73 \pm 0.39^{\mathrm{a}}$ & 2.53 & 14.03 & 2.96 & 1.32 & 0.44 & 0.22 & 0.40 & 5.30 \\
\hline S4T & $18.68 \pm 0.66^{\mathrm{de}}$ & $55.82 \pm 0.67^{\mathrm{j}}$ & $25.53 \pm 0.56^{\mathrm{b}}$ & $81.35 \pm 0.68^{\mathrm{def}}$ & $85.36 \pm 0.99^{\mathrm{ab}}$ & 2.51 & 13.32 & 2.99 & 1.37 & 0.46 & 0.22 & 0.40 & 5.69 \\
\hline S5R & $19.39 \pm 0.39^{\operatorname{defg}}$ & $50.13 \pm 0.67^{\mathrm{fg}}$ & $30.50 \pm 0.99^{\mathrm{efg}}$ & $80.63 \pm 0.37^{\text {cdef }}$ & $88.93 \pm 1.15^{\mathrm{cd}}$ & 1.80 & 16.27 & 2.59 & 1.57 & 0.61 & 0.22 & 0.40 & 5.15 \\
\hline S6T & $20.46 \pm 0.17^{\mathrm{efgh}}$ & $51.09 \pm 0.14^{\mathrm{gh}}$ & $28.49 \pm 0.29^{\mathrm{cd}}$ & $79.58 \pm 0.21^{\mathrm{bcd}}$ & $87.89 \pm 0.35^{\mathrm{bcd}}$ & 1.95 & 23.47 & 2.50 & 1.39 & 0.58 & 0.25 & 0.46 & 4.82 \\
\hline S7T & $19.48 \pm 1.18^{\text {defg }}$ & $47.61 \pm 0.54^{\mathrm{cd}}$ & $33.01 \pm 0.91^{\mathrm{i}}$ & $80.62 \pm 1.25^{\mathrm{cdef}}$ & $93.17 \pm 1.75^{\mathrm{fgh}}$ & 1.50 & 43.45 & 2.45 & 1.70 & 0.69 & 0.22 & 0.43 & 5.31 \\
\hline S8R & $18.45 \pm 0.13^{\text {cd }}$ & $49.28 \pm 0.52^{\mathrm{efg}}$ & $31.71 \pm 0.61^{\text {fghi }}$ & $81.60 \pm 0.14^{\mathrm{efg}}$ & $92.49 \pm 0.25^{\mathrm{fg}}$ & 1.66 & 63.84 & 2.70 & 1.72 & 0.63 & 0.21 & 0.41 & 5.67 \\
\hline S9T & $18.77 \pm 0.63^{\mathrm{bc}}$ & $49.13 \pm 0.41^{\mathrm{def}}$ & $35.99 \pm 0.68^{\mathrm{i}}$ & $85.13 \pm 0.62^{\mathrm{h}}$ & $94.76 \pm 0.89^{\text {ghij }}$ & 1.44 & 61.14 & 2.93 & 2.15 & 0.73 & 0.20 & 0.39 & 5.37 \\
\hline S10R & $19.63 \pm 0.26^{\operatorname{defg}}$ & $53.21 \pm 0.72^{\mathrm{i}}$ & $27.79 \pm 0.42^{\mathrm{c}}$ & $81.01 \pm 0.30^{\mathrm{def}}$ & $87.33 \pm 0.31^{\mathrm{bc}}$ & 2.10 & 15.14 & 2.70 & 1.46 & 0.52 & 0.22 & 0.40 & 5.09 \\
\hline S11T & $17.09 \pm 0.81^{\mathrm{c}}$ & $46.58 \pm 0.84^{\mathrm{bc}}$ & $35.46 \pm 0.20^{\mathrm{i}}$ & $82.03 \pm 0.19^{\mathrm{fg}}$ & $98.88 \pm 0.36^{1}$ & 1.37 & 15.35 & - & - & 0.76 & 0.20 & 0.37 & 5.85 \\
\hline $\mathrm{S} 12 \mathrm{R}$ & $20.03 \pm 0.31^{\text {defg }}$ & $52.11 \pm 0.17^{\mathrm{hi}}$ & $27.88 \pm 0.27^{\mathrm{c}}$ & $79.98 \pm 0.31^{\mathrm{cde}}$ & $92.57 \pm 0.52^{\mathrm{fg}}$ & 1.89 & 35.56 & 2.60 & 1.39 & 0.53 & 0.23 & 0.45 & 5.19 \\
\hline S13T & $18.67 \pm 0.52^{\mathrm{de}}$ & $50.30 \pm 0.49^{\mathrm{fg}}$ & $31.08 \pm 0.04^{\mathrm{ef}} \mathrm{gh}$ & $81.37 \pm 0.50^{\mathrm{def}}$ & $96.27 \pm 0.50^{\mathrm{k}}$ & 1.64 & - & 2.70 & 1.67 & 0.62 & 0.21 & 0.42 & 5.56 \\
\hline S14R & $20.26 \pm 0.93^{\text {efg }}$ & $49.73 \pm 0.40^{\mathrm{efg}}$ & $30.05 \pm 0.66^{\mathrm{def}}$ & $79.78 \pm 0.89^{\text {cde }}$ & $92.88 \pm 1.31^{\mathrm{fgh}}$ & 1.72 & - & 2.46 & 1.48 & 0.60 & 0.22 & 0.44 & 5.37 \\
\hline $\mathrm{AW}$ & $24.26 \pm 1.41^{\mathrm{i}}$ & $39.80 \pm 0.75^{\mathrm{a}}$ & $36.03 \pm 0.77^{\mathrm{i}}$ & $75.83 \pm 1.51^{\mathrm{a}}$ & $95.79 \pm 1.21^{\mathrm{ij}}$ & 1.11 & . & 1.65 & 1.50 & 0.91 & 0.29 & 0.58 & 4.41 \\
\hline IGO & $18.96 \pm 0.45^{\mathrm{def}}$ & $50.86 \pm 0.45^{\mathrm{gh}}$ & $30.18 \pm 0.03^{\mathrm{def}}$ & $81.04 \pm 0.45^{\mathrm{def}}$ & $93.76 \pm 0.77^{\text {fghij }}$ & 1.76 & - & 2.68 & 1.59 & 0.59 & 0.22 & 0.43 & 5.46 \\
\hline $\mathrm{RR}$ & $23.14 \pm 0.64^{\text {gh }}$ & $45.87 \pm 0.34^{\mathrm{b}}$ & $32.03 \pm 0.68^{\text {hij }}$ & $77.80 \pm 0.67^{b}$ & $92.02 \pm 1.08^{\text {ef }}$ & 1.45 & 228.54 & 1.98 & 1.38 & 0.70 & 0.22 & 0.44 & 5.93 \\
\hline RW & $20.76 \pm 0.29^{\mathrm{fgh}}$ & $45.94 \pm 0.24^{\mathrm{b}}$ & $34.95 \pm 0.20^{\mathrm{i}}$ & $80.89 \pm 0.43^{\text {def }}$ & $95.38 \pm 0.36^{\mathrm{hij}}$ & 1.34 & 158.78 & 2.21 & 1.68 & 0.76 & 0.22 & 0.44 & 6.10 \\
\hline EGT & $22.18 \pm 0.11^{\mathrm{hi}}$ & $57.01 \pm 0.08^{\mathrm{j}}$ & $22.00 \pm 0.24^{\mathrm{a}}$ & $79.01 \pm 0.17^{\mathrm{ab}}$ & $83.08 \pm 0.23^{\mathrm{a}}$ & 2.76 & 29.98 & 2.57 & 0.99 & 0.39 & 0.24 & 0.46 & 5.54 \\
\hline $\mathrm{RB}$ & $20.51 \pm 0.45^{\mathrm{fgh}}$ & $48.38 \pm 0.41^{\mathrm{de}}$ & $32.71 \pm 0.16^{\mathrm{h}}$ & $80.17 \pm 0.37^{\text {def }}$ & $93.72 \pm 0.36^{\mathrm{fghi}}$ & 1.53 & 52.32 & 2.35 & 1.59 & 0.68 & 0.21 & 0.40 & 6.53 \\
\hline
\end{tabular}

Data are expressed as percentages of total fatty acid methyl esters; Values are means of triplicate determinations, values followed by the same letter within each column are not significantly different ( $>>0.05)$ nd: not detected; GNC: Groundnut cultivar; S: Serenut; R: red; T: Tan; AW: Acholi White; IGO: Igola; RR: Rudu Red; RW: Rudu White; EGT: Egoromoit; RB: Red Beauty. S: saturated fatty acid; M: monounsaturated fatty acid; P: polyunsaturated fatty acid; TUFA: total unsaturated fatty acid; O/L: oleic/linoleic ratio; AI: Atherogenic index; TI: thrombogenic index; h/H: hypocholesterolemic to hypercholesterolemic index; IV: Iodine value. 


\subsection{Lipid Health Indices for Oyster Nut Oil}

The ratio of polyunsaturated to saturated fatty acids $(\mathrm{P} / \mathrm{S})$ is important in determining the cholesterolemic effect of dietary lipids. High $\mathrm{P} / \mathrm{S}$ ratios of $>1$ have a hypo-cholesterolemic effect and higher nutritional value than ones with less (Kostik et al., 2013). The P/S index of oyster nut oil ranged from 0.79 to 1.01 (Table 4). Nutritional guidelines show preference for $\mathrm{P} / \mathrm{S}>0.45$ (FAO, 2010). The $\mathrm{P} / \mathrm{S}$ ratio of oyster nut oil was within recommendations. The MUFA to SFA ratio (M/S) varied from 0.12 to 0.19 . Saturated FA have been suggested to increase cardiovascular risk while the converse is reported for MUFA (Grundy, 1997; De Souza et al., 2015; Iggman \& Risérus, 2017). Pacheco et al. (2006) studied the effect of different ratios of M/S and indicated that a low ratio resulted in pro-thrombic effect compared to a high ratio.

The $\omega 6 / \omega 3$ is an important indicator for decreasing the risk for coronary heart disease (CHD) and hypertension (Simopoulos, 2010). The total omega-3 FA content was $<0.5 \%$ while omega-6 FA proportions in oil which varied from 39.57 to $47.67 \%$ was several folds higher. Accordingly, the $\omega 6 / \omega 3$ of $>100$ was very high compared to the recommended ratio of < 4:1 (Simopoulos, 2002; 2004; Codex, 2005; Rustan and Drevon, 2005 and Patterson, Wall, Fitzgerald, Ross, \& Stanton, 2012). Oleic to linoleic acid ratio (O/L) is regarded as a measure of oil stability (Asibuo, 2008). Low O/L hence indicates low oxidative stability (Yanishlieva and Marinova, 2001). On the other hand a high ratio is desirable to enhance oxidative stability and nutritional value (Flagella, Rotunno, Tarantino, Di Caterina, \& De Caro, 2002; Mukri et al., 2012). Oyster nut oil had low O/L value of <1 (Table 4). The low $\mathrm{O} / \mathrm{L}$ ratio in oyster nut oil observed in this study implies that oyster nut oil is susceptible to oxidation.

Atherogenic index (AI) of oyster nut oil ranged from 0.57 to 1.09 while thrombogenic index (TI) ranged from 1.31 to 2.27. Antherogenic index values < 1 are desirable for cardiovascular health (Hernández-martínez et al., 2016). The AI for oyster nut oil was close to the recommended level however, the TI exceeded the desirable range of $<1$. This is attributed to almost balanced levels of SFA of 45.37 to $52.17 \%$ compared to the unsaturated FA range of 47.33 to $53.64 \%$ in the oil. The AI and TI observed for oyster nut oil were higher than those of bogue obtained from farmed fish reported by $\mathrm{S}^{\sim}$ imaT et al., (2015). The above indices varied from 0.53 to 0.61 and 0.29 to 0.35 for AI and TI, respectively for bogue. Thrombogenic index shows the tendency to form clots in the blood vessels (Ulbricht \& Southgate, 1991). This result implies that despite its vegetable origin, oyster nut oil may have potential to increase cardio vascular risk. The hypocholesterolemic to hypercholesterolemic index $(\mathrm{h} / \mathrm{H})$ indicates the influence of fatty acids on cholesterol metabolism (Hashempour-Baltork et al., 2018). The $\mathrm{h} / \mathrm{H}$ ranged from 0.06 to 1.57. There is no clear criterion for $\mathrm{h} / \mathrm{H}$ and health however, Osmari et al. (2011) and Hashempour-Baltork et al. (2018), suggested that higher values are beneficial to human health.

\subsection{Iodine Values of Oyster Nut Oil}

The iodine values (IV) of oil from oyster nuts ranged from 82.76 to 87.59 . The highest and lowest values were observed among nuts from Dokolo. The IV of oil from oyster nut is close to the 83.2 reported by (Hopkins \& Chisholm, 1964) for oyster nut oil. On the contrary, (Nyagah, 2016) obtained a higher value of 109 for oyster nut oil. Although the IV of oyster nut oil was not included in the codex standard for oils, the value is close to that of safflower and high oleic sun flower which range from 80 to 100 and 78 to 90, respectively. This confirms earlier reports which describe oyster nut oil as a drying oil (Ajayi, Dulloo, Vodouhe, Berjak, \& Kioko, 2004).

Table 4. Total fatty acids $(\%)$ and lipid health indices of oil from oyster nuts

\begin{tabular}{|c|c|c|c|c|c|c|c|c|c|c|c|c|c|c|}
\hline Source & Gender & SFA & MUFA & PUFA & TUFA & IV & $\mathrm{P} / \mathrm{S}$ & $\mathrm{P} / \mathrm{M}$ & $\mathrm{M} / \mathrm{S}$ & $\omega 6 / \omega 3$ & $\mathrm{O} / \mathrm{L}$ & AI & TI & $\mathrm{h} / \mathrm{H}$ \\
\hline Dokolo & Male & $52.17 \pm 1.50^{\mathrm{a}}$ & $6.23 \pm 0.30^{\mathrm{a}}$ & $41.10 \pm 0.98^{a}$ & $47.33 \pm 1.18^{\mathrm{a}}$ & $82.76 \pm 1.58^{a}$ & 0.79 & 6.6 & 0.12 & - & 0.15 & 1.09 & 2.19 & 0.06 \\
\hline Dokolo & Female & $48.89 \pm 6.66^{\mathrm{a}}$ & $8.42 \pm 2.10^{\mathrm{a}}$ & $45.22 \pm 2.36^{\mathrm{a}}$ & $53.64 \pm 2.18^{\mathrm{a}}$ & $87.59 \pm 4.90^{\mathrm{a}}$ & 0.94 & 5.6 & 0.18 & $3,938.98$ & 0.18 & 0.19 & 1.8 & 1.48 \\
\hline Kamuli & Male & $49.17 \pm 2.71^{\mathrm{a}}$ & $7.26 \pm 1.29^{\mathrm{a}}$ & $43.25 \pm 3.99^{\mathrm{a}}$ & $50.51 \pm 2.71^{\mathrm{a}}$ & $83.28 \pm 6.98^{\mathrm{a}}$ & 0.88 & 6.17 & 0.15 & - & 0.16 & 1.01 & 2.01 & 1.57 \\
\hline Kamuli & Female & $49.58 \pm 3.19^{\mathrm{a}}$ & $7.17 \pm 1.54^{\mathrm{a}}$ & $43.64 \pm 2.99^{a}$ & $50.81 \pm 2.28^{\mathrm{a}}$ & $84.45 \pm 7.04^{\mathrm{a}}$ & 0.89 & 6.33 & 0.23 & - & 0.16 & 0.94 & 1.87 & 1.38 \\
\hline Luwero & Male & $45.37 \pm 6.05^{\mathrm{a}}$ & $8.34 \pm 4.19^{a}$ & $45.25 \pm 1.82^{\mathrm{a}}$ & $53.59 \pm 5.58^{a}$ & $85.83 \pm 3.51^{\mathrm{a}}$ & 1.01 & 6.2 & 0.19 & 271.65 & 0.18 & 0.85 & 1.77 & 1.56 \\
\hline Luwero & Female & $46.77 \pm 3.84^{\mathrm{a}}$ & $7.12 \pm 1.65^{\mathrm{a}}$ & $44.33 \pm 2.63^{\mathrm{a}}$ & $51.45 \pm 2.85^{\mathrm{a}}$ & $86.91 \pm 4.77^{\mathrm{a}}$ & 0.95 & 6.47 & 0.16 & 262.54 & 0.16 & 0.57 & 1.79 & 1.57 \\
\hline
\end{tabular}

Values followed by the same letter within each row are not significantly different ( $p>0.05)$ nd: not detected; SFA: saturated fatty Acid; MUFA: Monounsaturated fatty acid; PUFA: Polyunsaturated fatty acid; TUFA: Total Unsaturated fatty acid; $\omega 6 / \omega 3$ : Omega-6 to Omega-3 ratio; O/L oleic to linoleic acid ratio; AI: Atherogenic index; TI: Thrombogenic index; h/H: Hypocholesterolemic to hypercholesterolemic index; IV: Iodine value.

\section{Conclusion}

Breeding may not affect major FA considering the similar levels of oleic acid, linoleic acid, palmitic and stearic acids. Oil from Serenut cultivars contained cis 11-eicosenoic acid (C20.1), cis 11, 14 eicosadienoic acid (C20.2) and cis 11, 14, 17 eicosatrienoic acid (C20.3 103$)$ but were not detected in that from traditional. This could imply 
that breeding enhanced the levels of these fatty acids in improved cultivars. Lipid health indices indicated that oil from groundnut cultivars were favourable for health. Oyster nut oil was abundant in linoleic and palmitic acid. Consequently, the ratio of total saturated FA to unsaturated FA was 1:1. The lipid health indices showed that consumption of oyster nut oil has potential to increase cardiovascular risk; however, the effect of individual SFA needs to be further examined.

\section{Acknowledgements}

This work was funded by African Development Bank through the Higher Education in Science and Technology (HEST V) project in partnership with Kyambogo University, Uganda. Authors are very grateful to Dr. David Okello Kalule and Dr. Michael Ugen of the National Semi-Arid Resources Research Institute (NaSARRI) Serere for providing Serenut groundnut cultivars.

\section{References}

Achola, E., Tukamuhabwa, P., Adriko, J., Edema, R., Mwale, S. E., Gibson, P., \& Okello, D. K. (2017). Composition and variation of fatty acids among groundnut cultivars in Uganda. African Crop Science Journal, 25(3), 291-299.

Ajayi, S. A., Dulloo, M. E., Vodouhe, R. S., Berjak, P., \& Kioko, J. I. (2004). Conservation status of Telfairia spp. in sub-Saharan Africa. In In Regional workshop on Plant Genetic Resources and food security in West and Central Africa. (pp. 89-95).

Ajayi, S. A., Dulloo, M. E., Vodouhe, R. S., Berjak, P. \&, \& Kioko, J. I. (2004). Conservation status of Telfairia spp. in sub-Saharan Africa. Ex Situ Conservation and Genetic Enhancement, (February 2015), 89-95.

Alabdulkarim, B., Bakeet, Z. A. N., \& Arzoo, S. (2012). Role of some functional lipids in preventing diseases and promoting health. Journal of King Saud University - Science, 24(4), 319-329.

https://doi.org/10.1016/j.jksus.2012.03.001

AOAC. (2000). AOAC Official Method 963.22 Methyl Esters of Fatty Acids in Oils and Fats, 1-2.

Arbex, A. K., Bizarro, V. R., Santos, J. C. S., Araújo, Lis Marina Mesquita Conceição de Jesus, Ana Luísa Fernandes, M. S. A., Miranda, M., \& Salles, Rocha. Denise. Rosso. Tenório. Wanderley \& Marcadenti, A. (2015). The Impact of the Essential Fatty Acids ( EFA ) in Human Health. Open Journal of Endocrine and Metabolic Diseases, 5(7), 98-104. https://doi.org/http://dx.doi.org/10.4236/ojemd.2015.57013

Asibuo, James Yaw, Akromah, Richard, Safo-Kantanka, Osei, Adu-Dapaah, Hans Kofi1, Ohemeng-Dapaah, S. and A. A. (2008). Chemical composition of groundnut, Arachis hypogaea (L)( L ) landraces. African Journal of Biotechnology, 7(13), 2203-2208.

Asibuo, J. (2008). Evaluation of nutritional quality of groundnut (Arachis hypogaea L.) from Ghana. African Journal of Food Agriculture Nutrition and Development, 8(2), 133-150.

Attia, Y. A., Al-harthi, M. A., Korish, M. A., \& Shiboob, M. M. (2015). hypocholesterolemic , atherogenic , and thrombogenic indices of table eggs in the retail market. Lipids in Health and Disease, 1-8. https://doi.org/10.1186/s12944-015-0133-z

Attia, Y. A., Al-harthi, M. A., Korish, M. A., \& Shiboob, M. M. (2017). Fatty acid and cholesterol profiles , hypocholesterolemic, atherogenic, and thrombogenic indices of broiler meat in the retail market. Lipids in Health and Disease, 16(40), 1-11. https://doi.org/10.1186/s12944-017-0423-8

Berry, S. K. (1982). Fatty acid composition of 16 groundnut (Arachis hypogaea, L.) cultivars grown under Malaysian conditions. Pertanika, 5(1), 20-24.

Bligh, E. ., \& Dyer, W. . (1959). A rapid method of total lipid extraction and purification. Canadian Journal of Biochemistry and Physiology, 37(8), 911-917.

Bonanome, A., \& Grundy, S. M. (1988). Effect of dietary stearic acid on plasma cholesterol and lipoprotein levels. Journal of Medicine, 318(19), 1244-1248.

Bos, M. B., Vries, J. H. M. De, Feskens, E. J. M., Dijk, S. J. Van, Hoelen, D. W. M., Siebelink, E., .. Groot, L. C. P. G. M. De. (2010). Effect of a high monounsaturated fatty acids diet and a Mediterranean diet on serum lipids and insulin sensitivity in adults with mild abdominal obesity *. Nutrition, Metabolism and Cardiovascular Diseases, 20(8), 591-598. https://doi.org/10.1016/j.numecd.2009.05.008

Calder, P. C. (2015). Functional Roles of Fatty Acids and Their Effects on Human Health Effects of Saturated Fatty Acids on. Journal of Parenteral and Enteral Nutrition, 39(1), 18S-32S. 
https://doi.org/10.1177/0148607115595980

Carta, G., Murru, E., Banni, S., \& Manca, C. (2017). Palmitic Acid: Physiological Role , Metabolism and Nutritional Implications. Frontiers in Physiology, 8(902), 1-14. https://doi.org/10.3389/fphys.2017.00902

Codex. (2005). Codex Alimentarius, FAO/ WHO, Rome, Italy. Codex-Stan 210, Codex Standard for Named Vegetable Oils, 8(2).

de Souza, R. J., Mente, A., Maroleanu, A., Cozma, A. I., Ha, V., Kishibe, T., ... Anand, S. S. (2015). Intake of saturated and trans unsaturated fatty acids and risk of all cause mortality, cardiovascular disease, and type 2 diabetes: systematic review and meta-analysis of observational studies. British Medical Journal, 351, h3978. https://doi.org/10.1136/bmj.h3978

Dorni, C., Paras, S., Gunendra, S., \& Longvah, T. (2018). Fatty acid Profile of edible oils and fats consumed in India. Food Chemistry, 238, 9-15.

FAO. (2010). Fats and fatty acids in human nutrition, Report of an expert consultation 10-14 November 2008, FAO Food and Nutrition paper 91. Rome.

Fattore, E., \& Fanelli, R. (2013). Palm oil and palmitic acid: A review on cardiovascular effects and carcinogenicity Palm oil and palmitic acid: a review on cardiovascular effects and carcinogenicity. International Journal of Food Sciences and Nutrition, 64(5), 648-659. https://doi.org/10.3109/09637486.2013.768213

Flagella, Z., Rotunno, T., Tarantino, E., Di Caterina, R., \& De Caro, A. (2002). Changes in seed yield and oil fatty acid composition of high oleic sunflower (Helianthus annuus L.) hybrids in relation to the sowing date and the water regime. European Journal of Agronomy, 17(3), 221-230.

Galli, C., \& Calder, P. C. (2009). Effects of fat and fatty acid intake on inflammatory and immune responses: A critical review. Annals of Nutrition and Metabolism, 55(1-3), 123-139. https://doi.org/10.1159/000228999

Grundy, S. M. (1997). What is the desirable and monounsaturated ratio of saturated, polyunsaturated, fatty acids in the diet? 1'2. American Journal of Clinical Nutrition, 66(Suppliment), 988S-90S.

Harlioğlu, A. G., \& Yilmaz, Ö. (2011). Fatty acid composition, cholesterol and fat-soluble vitamins of wild-caught freshwater spiny eel, Mastacembelus simack (Walbaum, 1792). Journal of Applied Ichthyology, 27(4), 1123-1127. https://doi.org/10.1111/j.1439-0426.2011.01750.x

Hashempour-Baltork, F., Torbati, M., Azadmard-Damirchi, S., \& Savage, G. P. (2018). Chemical, rheological and nutritional characteristics of sesame and olive oils blended with linseed oil. Advanced Pharmaceutical Bulletin, 8(1), 107-113. https://doi.org/10.15171/apb.2018.013

Hashim, I. B., Koehlerv, P. E., Eitenmiller, R. R., \& Kvien, C. K. (1993). Fatty Acid Composition and Tocopherol Content of Drought Stressed Florunner Peanuts, 21-24.

Hernández-martínez, M., Gallardo-velázquez, T., Osorio-, G., Castañeda-pérez, E., \& Uribe-hernández, K. (2016). Characterization of Mexican Fishes According to Fatty Acid Profile and Fat Nutritional Indices Characterization of Mexican Fishes According to Fatty Acid Profile and Fat Nutritional Indices. International Journal of Food Properties, 19(6), 1401-1412.

https://doi.org/10.1080/10942912.2015.1079787

Hollis, J., \& Mattes, R. (2007). Effect of chronic consumption of almonds on body weight in healthy humans. The British Journal of Nutrition, 98(3), 651-656. https://doi.org/10.1017/S0007114507734608

Hopkins, C. Y., \& Chisholm, M. . (1964). Fatty acid composition of some cucurbitaceae seed oils. Canadian Journal of Chemistry, 42(7785), 560-564.

Iggman, D., \& Risérus, U. (2017). Role of different dietary saturated fatty acids for cardiometabolic risk Role of different dietary saturated fatty acids for cardiometabolic risk. Clinical Liipidology, 4299, 1758-4302.

Johnson, S., Saikia, N., Mathur, H. ., \& Agarwal, H. . (2009). Fatty acids profile of Edible Oils and Fats in India (No. CSE/PML/PR-32/2009). Centre for Science and Environment. New Delhi.

Jumbe, T. J., Pickens, C. A., Valentini, K., Adjepong, M., Li, W., Kinabo, J. L., \& Fenton, J. I. (2016). Evaluation of fatty acid and mineral content of Tanzanian seeds and oils. Journal of Food Composition and Analysis, 50, 108-113. https://doi.org/10.1016/j.jfca.2016.05.016

Khetarpaul, N., Jood, S., \& Goyal, R. (2007). Fatty acid composition and phisico-chemical chracteristics of cooking oils and thier blends. Journal of Dairying, Foods and Homesciences, 26(3/4), 202-208. 
Kostik, V., Memeti, S., \& Bauer, B. (2013). Fatty acid composition of edible oils and fats. Journal of Hygienic Engineering and Design, 112-116.

Kou, L., Sabolová, M., Hor, P., \& Rys, S. (2018). Lipid content , fatty acid pro fi le , and nutritional value of new oat cultivars. Journal of Cereal Science, 84(September), 44-48. https://doi.org/10.1016/j.jcs.2018.09.012

Kris-Etherton, P. M. (1999). Monousaturated Fatty Acids and Risk of Cardiovascular Disease. Circulation, 8721(71), 1253-1258. https://doi.org/10.1111/j.1751-7117.2009.00028.x

Kris-Etherton, P. M., Yu-Poth, S., Sabate, J., Ratcliffe, H. E., Zhao, G., \& Etherton, T. D. (1999). Nuts and their bioactive constituents: effects on serum lipids and other factors that affect disease risk. The American Journal of Clinical Nutrition, 70(3), 504S-511S. Retrieved from http://ajen.nutrition.org/content/70/3/504s.short

Mancini, A., Imperlini, E., Nigro, E., Montagnese, C., Daniele, A., Orrù, S., \& Buono, P. (2015). Biological and Nutritional Properties of Palm Oil and Palmitic Acid: Effects on Health. Molecules, 20, 17339-17361. https://doi.org/10.3390/molecules200917339

Mente, A., Dehghan, M., Rangarajan, S., McQueen, M., Dagenais, G., Wielgosz, A., \& Wang, Y. (2017). Association of dietary nutrients with blood lipids and blood pressure in 18 countries: a cross-sectional analysis from the PURE study. The Lancet Diabetes \& Endocrinology, 5(10), 774-787. https://doi.org/10.1016/S2213-8587(17)30283-8

Minzangi, K., Mpiana, P. T., Samvura, B., Kaaya, A. N., Bertrand, M., \& Kadima, J. N. (2015). Composition of Fatty Acids and Tocopherols Content in Oilseeds of Six Wild Selected Plants from Kahuzi-Biega National Park/DR. Congo. European Journal of Medicinal Plants, 8(3), 157-166. https://doi.org/10.9734/EJMP/2015/17297

Mugisha, J., Lwasa, S., \& Mausch, K. (2014). Value chain analysis and mapping for groundnuts in Uganda.

Mukri, G., Adaf, H. ajisaheb L. N., Bhat, R. S. B., Gowda, M. V. C. G., Upadhyaya, H. ., \& Sujay, V. (2012). Phenotypic and molecular dissection of ICRISAT mini core collection of peanut (Arachis hypogaea L .) for high oleic acid. Plant Breeding, 422(131), 418-422. https://doi.org/10.1111/j.1439-0523.2012.01970.x

Nile, S. H., \& Park, S. W. (2013). Fatty Acid Composition and Antioxidant Activity of Groundnut ( Arachis hypogaea L .) Products. Food Science and Technology Research, 19(6), 957-962. https://doi.org/10.3136/fstr.19.957

Ntare, B. R., Diallo, A. T., Ndjeunga, J., \& Waliyar, F. (2008). Groundnut Seed Production Manual.

Nyagah, P. K. (2016). The potential of Telfairia pedata for liquid biofuel and soap production. Kenyatta University.

Okello, D. K., Biruma, M., \& Deom, C. M. (2010). Overview of groundnuts research in Uganda: Past, present, and future. African Journal of Biotechnology, 9(39), 6448-6459. https://doi.org/10.5897/AJB09.013

Okello, D. K., Deom, C. M., Puppala, N., Monyo, E., \& Bravo-Ureta, B. (2016). Registration of 'Serenut 5R' Groundnut. Journal of Plant Registrations, 10(2), 1-4. https://doi.org/10.3198/jpr2015.07.0041crc

Osmari, E. K., Cecato, U., Macedo, F. A. F., \& Souza, N. E. (2011). Nutritional quality indices of milk fat from goats on diets supplemented with different roughages. Small Ruminant Research, 98(1-3), 128-132. https://doi.org/10.1016/j.smallrumres.2011.03.030

Özcan, M. M. (2010). Some nutritional characteristics of kernel and oil of peanut (Arachis hypogaea L.). Journal of Oleo Sci, 59(1), 1-5.

Pacheco, Y. M., Berm??dez, B., L??pez, S., Abia, R., Villar, J., \& Muriana, F. J. G. (2006). Ratio of oleic to palmitic acid is a dietary determinant of thrombogenic and fibrinolytic factors during the postprandial state in men. American Journal of Clinical Nutrition, 84(2), 342-349.

Patterson, E., Wall, R., Fitzgerald, G. F., Ross, R. P., \& Stanton, C. (2012a). Health Implications of High Dietary Omega-6 Polyunsaturated Fatty Acids. Nutrition and Metabolism, 2012, 1-16. https://doi.org/10.1155/2012/539426

Patterson, E., Wall, R., Fitzgerald, G. F., Ross, R. P., \& Stanton, C. (2012b). Health Implications of High Dietary Omega-6 Polyunsaturated Fatty Acids, 2012. https://doi.org/10.1155/2012/539426

Ramprasath, V. R., Jones, P. J. H., Buckley, D. D., Woollett, L. A., \& Heubi, J. E. (2012). Decreased plasma cholesterol concentrations after pufa-rich diets are not due to reduced cholesterol absorption/synthesis. 
Lipids, 47(11), 1063-1071. https://doi.org/10.1007/s11745-012-3708-8

Ristić-Medić, D., Vučić, V., Takić, M., \& Karadžić, Ivana and Glibetić, M. (2013). Polyunsaturated fatty acids in health and disease. Journal of the Serbian Chemical Society, 78(9), 1269-1289. https://doi.org/10.2298/JSC130402040R

Rustan, A. C., \& Drevon, C. A. (2005). Fatty Acids: Structures and Properties. Encyclopedia of Life Sciences, 1-7. https://doi.org/10.1038/npg.els.0003894

S`imaT, V., Bogdanovic', T., Poljak, V., \& Petric`evic', S. (2015). Changes in fatty acid composition , atherogenic and thrombogenic health lipid indices and lipid stability of bogue (Boops boops Linnaeus, 1758 ) during storage on ice : Effect of fish farming activities. Journal of Food Composition and Analysis, 40, 120-125. https://doi.org/10.1016/j.jfca.2014.12.026

Santos-Silva, J., Bessa, R. J. B., \& Santos-Silva, F. (2002). Effect of genotype, feeding system and slaughter weight on the quality of light lambs: II. Fatty acid composition of meat. Livestock Production Science, 77(2-3), 187-194.

Shad, M. A., Pervez, H., Zafar, Z. I., Nawaz, H., \& Khan, H. (2012). Physicochemical properties, fatty acid profile and antioxidant activity of Peanut Oil. Pakistan Journal of Botany, 44(1), 435-440.

Shahidi, F. E. (2005). Bailey's industrial oil and fat products: Volume 1, Edible Oil and Fat Products: Chemistry, Properties, and Health Effects. (F. Shahidi, Ed.) (6th ed.). Hoboken, New Jersey: JOHN WILEY \& SONS, INC.

Simopoulos, A. P. (2008). The Importance of the Omega-6/Omega-3 Fatty Acid Ratio in Cardiovascular Disease and Other Chronic Diseases. Experimental Biology and Medicine, 233(6), 674-688. https://doi.org/10.3181/0711-MR-311

Simopoulos AP. (2002). The importane of the ratio of omega-6/omega-3 essential fatty acids. Biomedicine and Pharmacotherapy, 8(56), 365-379.

Simopoulos, Artemis. P. (2010). The omega-6 / omega-3 fatty acid ratio : health implications. Oilseeds and Fats, Crops and Lipids, 17(5), 267-275. https://doi.org/http://dx.doi.org/10.1051/ocl.2010.0325

Simopoulos, Artemis. P. (2016). An Increase in the Omega-6 / Omega-3 Fatty Acid Ratio Increases the Risk for Obesity. Nutrients, 8(3), 1-17. https://doi.org/10.3390/nu8030128

Simopoulos, Artemis P. (2004). Omega-6/Omega-3 Essential Fatty Acid Ratio and Chronic Diseases. Food Reviews International, 20(1), 77-90. https://doi.org/10.1081/FRI-120028831

Sinanoglou, V. J., Batrinou, A., Mantis, F., Bizelis, I., \& Miniadis-meimaroglou, S. (2013). Lipid quality indices : Differentiation of suckling lamb and kid breeds reared by traditional sheep farming. Small Ruminant Research, 113(1), 1-10. https://doi.org/10.1016/j.smallrumres.2013.01.008

Strayer, D., Belcher, M., Fine, J., \& Mcbrayer, T. (2006). Food Fats (9th ed.). Washington: Institute of Shortening and Edible Oils , Inc.

Turan, H., Sönmez, G., \& Kaya, Y. (2007). Fatty acid profile and proximate composition of the thornback ray ( Raja clavata , L . 1758 ) from the Sinop coast in the Black Sea. Journal of Fisheries Sciences.Com, 1(2), 97-103. https://doi.org/10.3153/jfscom.2007012

Ulbricht, T. L. V., \& Southgate, D. A. T. (1991). Coronary heart disease: seven dietary factors. The Lancet, 338(8773), 985-992.

Wen, N., \& Chao, P. (1998). Effects of the Ratio of Polyunsaturated and Monounsaturated Fatty Acid to Saturated Fatty Acid on Rat Plasma. Lipids, 33(5), 481-487.

Yang, S.-C., Lin, S.-H., Chang, J.-S., \& Chien, Y.-W. (2017). High Fat Diet with a High Monounsaturated Fatty Acid and Polyunsaturated / Saturated Fatty Acid Ratio Suppresses Body Fat Accumulation and Weight Gain. Nutrients, 9(10), 1-15. https://doi.org/10.3390/nu9101148

Yanishlieva, N. V., \& Marinova, E. M. (2001). Stabilisation of edible oils with natural antioxidants. European journal of lipid science and technology. European Journal of Lipid Science and Technology, 103(11), $752-767$.

Yehuda, S. (2003). Omega-6/omega-3 ratio and brain-related functions. In Omega-6/Omega-3 Essential Fatty Acid Ratio: The Scientific Evidence .Karger Publishers., 92, 37-56. https://doi.org/10.1159/000073791 


\section{Copyrights}

Copyright for this article is retained by the author(s), with first publication rights granted to the journal.

This is an open-access article distributed under the terms and conditions of the Creative Commons Attribution license (http://creativecommons.org/licenses/by/4.0/). 